\title{
Identification of the Constructs Related to IT Investment on Supply Chain Integration for Improving the Firm Performance
}

\author{
Shrawan Kumar Trivedi \\ Information Systems \\ Indian Institute of Management \\ Prabandh Shikhar, \\ Rau Indore - 453 556, India
}

\author{
Kapil Kaushik \\ Information Systems \\ Indian Institute of Management \\ Prabandh Shikhar \\ Rau Indore -453556 , India
}

\begin{abstract}
This research examines the impact of IT investment on the cost structure of the firm and it also explores the different factors related to IT investment that directly or indirectly can affect the automation process of supply chain as well as performance of the firm. After the brief literature survey this paper identifies different independent variables such as internal and external integration, physical and information integration, use of technology, external environmental condition, internal operational characteristics and appropriate technology. These variables have been identified as important for the automation process of supply chain integration with the use of information technology. Further this paper have taken these variables (dependent and independent) for making a robust model where independent variables are used to improve the automation process of supply chain integration for minimizing production and coordination cost and hence improve the firm performance. The presented model can be further taken for validating empirically.
\end{abstract}

\section{Keywords}

IT Investment, Supply Chain Integration, Production cost, Transaction Cost, Coordination cost, Cost function, Firm performance.

\section{INTRODUCTION}

There are evidences seen in the literature which show the impact of Information technology investment on the various measurement of performance of the firms. Firms invest in these technologies to gain productivity. It has been seen from various studies that investment in the information technology impacts on the firm's product efficiency and product quality both. Information technologies reduce the firms' overhead costs without compromising on their quality and pricing decision but increase the profit and improve productivity. The impact of information technology can be seen in the firms' Production efficiency, Product quality and Pricing decisions, Production cost and Profit \& Productivity. This research has been focused on the impact of the Information technology on the production cost as well as cost of monitoring task completion.

\subsection{Production Cost}

There is several cost components involved in manufacturing a product. Firms invest in technologies for reducing these costs and increasing the production efficiency as well as in improving quality. They hope to get a significant return on these investments. Production costs involve various types of the cost in their cost function $[3,4,7]$.

\subsection{Cost Function}

Cost function can be seen as the combination of the several cost elements. The first element of the cost function is amortized fixed costs of doing business, or indirect costs, including building rent, depreciation, and maintenance of equipment, as well as utility costs. Also it includes the costs of acquiring, implementing and maintaining technology (e.g. hardware, software, processes and methodology) to maintain or improve the firm's production capability. This first element of the cost function enables the production in the firms but it does not incorporate the quality and quantity of the product $[4$, 5].

Some other elements in the cost function are direct production costs incurred by the firm. In order to offer a product to the consumer, firms need to design and develop the product according to consumer preference. They need to design and develop products that will be offered. That is, the firm must determine the combination of features (e.g., performance. Reliability, efficiency, convenience, variety and technical support), which defines the product of a certain level of quality that meets customer requirements. This process represents a significant cost of installation and can include functions such as research and development, prototyping and usability testing

\section{THEORY}

2.1 Cost of monitoring task completion some additional costs are also associated in the cost structure. These cost are basically the cost involve in the tracking the individual task. These costs can range from task involved in the development of a product to delivery of that product. By the use of information technology these costs can be lowered. These costs involve the cost associated with Remote monitor, Alert and response, Asset management, Maintenance costs, Monthly reporting and security related costs.

These two costs can be easily determined by the Production economies and Transaction economies. Two kinds of theories have been seen in the context of the production; these are Neo classical theory and Transaction cost theory. These theories can be applicable for different kinds of condition such as perfect and imperfect competition and these are concerned with production and coordination cost, respectively. Under the perfect competition there would be no cost associated with market exchange and goods would be transferred between parties at the price that reflect production cost.

\subsection{Production Economies}

"Neoclassical economics theory" considers any business organization as the "production function" which is motivated by profit maximization. Firms provide goods and services to 
market which helps in achieving benefits and rely on those markets in which they have comparative cost disadvantage. Neoclassical economics predicts that companies justify sourcing decisions based on the production economies. With regard to Production economies, buying goods and services is seen as an economical make or buying decision, which compares the Production cost of internal operations compared to the price offered in the market. Firms choose the outsourcing or in sourcing activities based on cost associated with the internalizing the information system compared to the price which will pay to the vendors for the same information services [1].

\subsection{Transaction Economies}

\section{RELATED WORK}

Plethora of research has been done that captures the Impact of IT Investment on Firm Performance which have been given on Table 1.

Table 1: Related Work

\begin{tabular}{|c|c|c|c|c|}
\hline Paner Title & A uthor Name & Yeor & Poper Type & KevIdea \\
\hline $\begin{array}{l}\text { Firm performance impacts of } \\
\text { digitally enabled supply chain } \\
\text { integration capabilities }\end{array}$ & $\begin{array}{c}\text { Rai, A., } \\
\text { Patnayakuni, R., } \\
\text { \& Seth, N.[12] }\end{array}$ & 2006 & Empirical & $\begin{array}{l}\text { IT enabled Supply chain integration helps } \\
\text { organization to unbundle information flow } \\
\text { from physical flow,sharing information with } \\
\text { partners and better demand planning. Thus IT- } \\
\text { enabled Supply chain integration capability } \\
\text { leads to significant performance gains. }\end{array}$ \\
\hline $\begin{array}{l}\text { The impact of information } \\
\text { technology on supply chain } \\
\text { capabilities and firm } \\
\text { performance: a resource-based } \\
\text { view }\end{array}$ & $\begin{array}{c}\text { Wu, F., } \\
\text { Yeniyurt, S., } \\
\text { Kim, D., \& } \\
\text { Cavusgil, S. T. } \\
\quad \text { [13] }\end{array}$ & 2006 & Empirical & $\begin{array}{l}\text { This research explores the mediation effect of } \\
\text { Supply chain capabilities on relationship } \\
\text { between IT investment and firm performance. } \\
\text { Through embedding IT into firm's supply chain } \\
\text { system firm is able to respond to market } \\
\text { changes quickly and may gain sustainable } \\
\text { competitive advantage. }\end{array}$ \\
\hline $\begin{array}{l}\text { The financial performance effects } \\
\text { of IT-based supply chain } \\
\text { management systems in } \\
\text { manufacturing firms }\end{array}$ & $\begin{array}{l}\text { Dehning, B., } \\
\text { Richardson, V. } \\
\text { J., \& Zmud, R. } \\
\text { W. [14] }\end{array}$ & 2007 & Empirical & $\begin{array}{l}\text { This Paper analyzes the financial benefits of IT } \\
\text { investments around newly adopted Supply } \\
\text { chain systems. The Results revealed that SCM } \\
\text { systems increase gross margin, inventory } \\
\text { turnover, market share, return on sales, and } \\
\text { reduce selling, general, and administrative } \\
\text { expenses. }\end{array}$ \\
\hline $\begin{array}{l}\text { Examining possible antecedents } \\
\text { of IT impact on the supply chain } \\
\text { and its effect on firm performance }\end{array}$ & $\begin{array}{c}\text { Byrd, T. A., \& } \\
\text { Davidson, N. W. } \\
{[15]}\end{array}$ & 2003 & Empirical & $\begin{array}{l}\text { This paper analyzes the impact of IT on supply } \\
\text { chain and effect IT-enabled supply chain on } \\
\text { overall firm performance. The results revealed } \\
\text { positive impact of IT on the supply chain and } \\
\text { firm performance. }\end{array}$ \\
\hline $\begin{array}{c}\text { The impact of IT implementation } \\
\text { on supply chain integration and } \\
\text { performance }\end{array}$ & $\begin{array}{l}\text { Li, G., Yang, H., } \\
\text { Sun, L., \& } \\
\text { Sohal, A. S. [16] }\end{array}$ & 2009 & Empirical & $\begin{array}{l}\text { This study investigates relationship among } \\
\text { three factors : IT implementation, Supply chain } \\
\text { integration and supply chain performance. It } \\
\text { suggests that IT enhances Supply chain } \\
\text { performance through it's positive impact on } \\
\text { Supply chain integration. }\end{array}$ \\
\hline $\begin{array}{l}\text { Achieving supply chain agility } \\
\text { through IT integration and } \\
\text { flexibility }\end{array}$ & $\begin{array}{l}\text { Swafford, P. M., } \\
\text { Ghosh, S., \& } \\
\text { Murthy, N. [17] }\end{array}$ & 2008 & Empirical & $\begin{array}{l}\text { This paper discusses the role of IT integration } \\
\text { and flexibility in achieving supply chain agility. } \\
\text { The results from this study reveals that IT } \\
\text { integration lead to supply chain integration } \\
\text { which in turn lead to higher supply chain agility } \\
\text { and finally higher competitive business } \\
\text { performance. }\end{array}$ \\
\hline $\begin{array}{c}\text { Modeling the relationship } \\
\text { between firm IT capability, } \\
\text { collaboration, and performance }\end{array}$ & $\begin{array}{l}\text { Sanders, N. R., } \\
\text { \& Premus, R. } \\
{[18]}\end{array}$ & 2005 & Empirical & $\begin{array}{l}\text { This study proposes and tests model of the } \\
\text { relationship between firm IT capability, extent } \\
\text { of internal and external organizational } \\
\text { collaboration, and firm performance. It is } \\
\text { shown in results that IT has a significant direct } \\
\text { impact on performance and a significant impact } \\
\text { on both external and internal collaboration. }\end{array}$ \\
\hline
\end{tabular}
economic perspective of the firm, recognizing the importance of transaction costs in any market exchange. Transaction costs related to effort, time and costs associated with searching, creating, negotiating, monitoring and enforcement of the contract for services between buyers and suppliers. Transaction costs could undermine the comparative advantage in manufacturing suppliers. When a firm has to bear a considerable strength and resources to supervising, coordinating and monitoring the activities of vendors, it may decide that external sourcing is too expensive. Thus, companies can choose an internal sourcing when they perceive a negative effect of the transaction to override any production cost benefits at market exchange [1]. 


\section{RESEARCH MODEL}

After going through the literature it has been seen that there is very less empirical work done in the integration activities supply chain activity by the use of information technology, which can be impacted on the firm performance by reducing the production cost. Evidence from the literature says that, information system plays an important role in integrating the supply chain activities and internal production processes. There are lots of factor has been seen, which impact on the integration of the supply chain and internal processes and which directly related to the production as well as coordination cost. Some of the literature focused on the contingency theory for these integrations.

"Contingency Theory" argues that firm's performance can be attributed to the match between the strategic behavior and its internal and external environment. This match may require the

\subsection{Dependent variable}

Supply chain Integration with the use of Information Technology.

Table 2: Variable Descriptions adoption of the organizational processes and strategies, taking into account the specific circumstances being faced by the company. Contingency theory considers the firm as an open system in which information is exchanged through the inputprocess-output procedure. "Input" refers to the contextual issues (e.g., functional coordination, and fluctuations in demand), residing within or outside the organizational boundaries, creating uncertainties and opportunities, and thus affecting the company's need to work in Supply Chain. "Process" concerns institutional arrangements to manage and cope with the contextual issues through information sharing and coordination of business processes. "Output" refers to the results of this process procedures, which reflect how the business processes, adapt or eliminate the problems associated with the environment (e.g., input) [2].

\begin{tabular}{|c|c|c|}
\hline $\begin{array}{c}\text { Ind. Variables } \\
\begin{array}{c}\text { Internal and external } \\
\text { integration }\end{array}\end{array}$ & $\begin{array}{c}\text { Description } \\
\text { from material management to production, sale, } \\
\text { and distribution } \\
\text { External: Customer and supplier integration. }\end{array}$ & Related Papers \\
\hline $\begin{array}{c}\text { Physical and } \\
\text { Information } \\
\text { integration }\end{array}$ & $\begin{array}{c}\text { Physical: dealing with the flow and storage of } \\
\text { goods } \\
\text { Information: dealing with information } \\
\text { associated with those goods. }\end{array}$ & $\begin{array}{c}\text { Ira Lewis and } \\
\text { Alexander Talalayevsky } \\
\text { [9] }\end{array}$ \\
\hline $\begin{array}{c}\text { Use of technology } \\
\text { Envifference in firms create the different } \\
\text { perception in terms of use of technology }\end{array}$ & $\begin{array}{c}\text { Craig A. Hill, Gary D. } \\
\text { Scudder [10] }\end{array}$ \\
\hline $\begin{array}{c}\text { External } \\
\text { operational } \\
\text { characteristics }\end{array}$ & $\begin{array}{c}\text { Environmental uncertainty has a positive } \\
\text { impact on virtual integration, supplier } \\
\text { responsiveness, and manufacturing flexibility. }\end{array}$ & $\begin{array}{c}\text { Kee-hung Lai, and T.c.e. } \\
\text { Cheng [11] }\end{array}$ \\
\hline $\begin{array}{c}\text { Appropriate } \\
\text { Technology }\end{array}$ & Choice of technology should be compatible \\
with the task. & $\begin{array}{c}\text { Rudolf R. Sinkovics . } \\
\text { Ruey-Jer Bryan' Jean } \\
\text { Anthony S. Roath } \\
\text { S.Tamer Cavusgil [8] }\end{array}$ \\
\hline
\end{tabular}

\section{MODEL TESTING STEPS}

For testing the model we have follow some steps given bellow:

- Firstly, required hypothesis will be produced for relating all independent variables with the dependent variable.

- In this model because case studies can be found so some item can be generated which can well define our independent variables. And then test the reliability of the items will be performed, by the use of Correlation, factor analysis and alpha value with help of regression.

- After above steps, some respondent can be picked from same firms for taking observation and generating data for testing the model.

- Then questionnaire will be generated which can capture all the items and easily predict variables of the model.

- Some interviews will also be captured for taking appropriate information about internal activities of the selected firm.

- After gathering the data we will run ANOVA and some method for testing our hypotheses.
- Then by the use of hypotheses, we can get a position to say about accurate picture of our model and based on that we can give some managerial implication.

\section{CONCLUSION}

Investment in the appropriate information technology at the right time is necessary for being competitive and sustainable for the firm. Manager of a company should take strategic IT investment decisions so that performance of firm can be improved with the minimizations of coordination and production cost. With these challenges, Research has been done where the aim was to identify appropriate information technology related independent variables that directly or indirectly affect the integration of supply chain for improving the firm performance. The aim was successfully achieved where this paper ends with a model that clarify the exact situation so that the manager of a company can take appropriate decision for IT investment to improve firm performance.

In future some or more variables can be added in the presented model to make it more reliable. Also the given model can be empirically validated by taking the appropriate information technology data of organization. 


\section{REFERENCES}

[1] Ang, S., \& Straub, D. W. (1998). Production and Transaction Economies and IS Outsourcing: A Study of the US Banking Industry. MIS quarterly, 22(4).

[2] Wilkinson, I., \& Nguyen, V. (2002). A Contingency Model of Export Entry Mode Performance. UNSW School of Marketing Working Paper, (02/2).:

[3] Dyer, J. H., \& Chu, W. (2003). The role of trustworthiness in reducing transaction costs and improving performance: Empirical evidence from the United States, Japan, and Korea. Organization science, 14(1), 57-68

[4] Menon, N. M., \& Lee, B. (2000). Cost control and production performance enhancement by IT investment and regulation changes: evidence from the healthcare industry. Decision Support Systems, 30(2), 153-169.

[5] Thatcher, M. E., \& Pingry, D. E. (2004). Understanding the business value of information technology investments: Theoretical evidence from alternative market and cost structures. Journal of Management Information Systems, 21(2), 61-85.

[6] Brynjolfsson, E., \& Hitt, L. (1995). Information technology as a factor of production: The role of differences among firms. Economics of Innovation and New technology, 3(3-4), 183-200.

[7] Boon-itt, S. (2009, December). The role of information technology and supply chain integration on production cost performance. In Industrial Engineering and Engineering Management, 2009. IEEM 2009. IEEE International Conference on(pp. 1464-1468). IEEE.

[8] Sinkovics, R. R., Jean, A. P. R. J. B., \& Cavusgil, S. T. (2011). Does IT integration really enhance supplier responsiveness in global supply chains?.Management International Review, 51(2), 193-212.

[9] Lewis, I., \& Talalayevsky, A. (2004). Improving the interorganizational supply chain through optimization of information flows. Journal of Enterprise Information Management, 17(3), 229-237.
[10] Hill, C. A., \& Scudder, G. D. (2002). The use of electronic data interchanges for supply chain coordination in the food industry. Journal of Operations Management, 20(4), 375-387.

[11] Wong, C. W., Lai, K. H., \& Cheng, T. C. (2011). Value of information integration to supply chain management: roles of internal and external contingencies.Journal of Management Information Systems, 28(3)161-200.

[12] Rai, A., Patnayakuni, R., \& Seth, N. (2006). Firm performance impacts of digitally enabled supply chain integration capabilities. MIS quarterly, 225-246.

[13] Wu, F., Yeniyurt, S., Kim, D., \& Cavusgil, S. T. (2006). The impact of information technology on supply chain capabilities and firm performance: a resource-based view. Industrial Marketing Management, 35(4), 493504.

[14] Dehning, B., Richardson, V. J., \& Zmud, R. W. (2007). The financial performance effects of IT-based supply chain management systems in manufacturing firms. Journal of Operations Management, 25(4), 806824

[15] Byrd, T. A., \& Davidson, N. W. (2003). Examining possible antecedents of IT impact on the supply chain and its effect on firm performance. Information \& Management, 41(2), 243-255.

[16] Li, G., Yang, H., Sun, L., \& Sohal, A. S. (2009). The impact of IT implementation on supply chain integration and performance. International Journal of Production Economics, 120(1), 125-138.

[17] Swafford, P. M., Ghosh, S., \& Murthy, N. (2008). Achieving supply chain agility through IT integration and flexibility. International Journal of Production Economics, 116(2), 288-297.

[18] Sanders, N. R., \& Premus, R. (2005). Modeling the relationship between firm IT capability, collaboration, and performance. Journal of Business Logistics, 26(1), $1-23$.

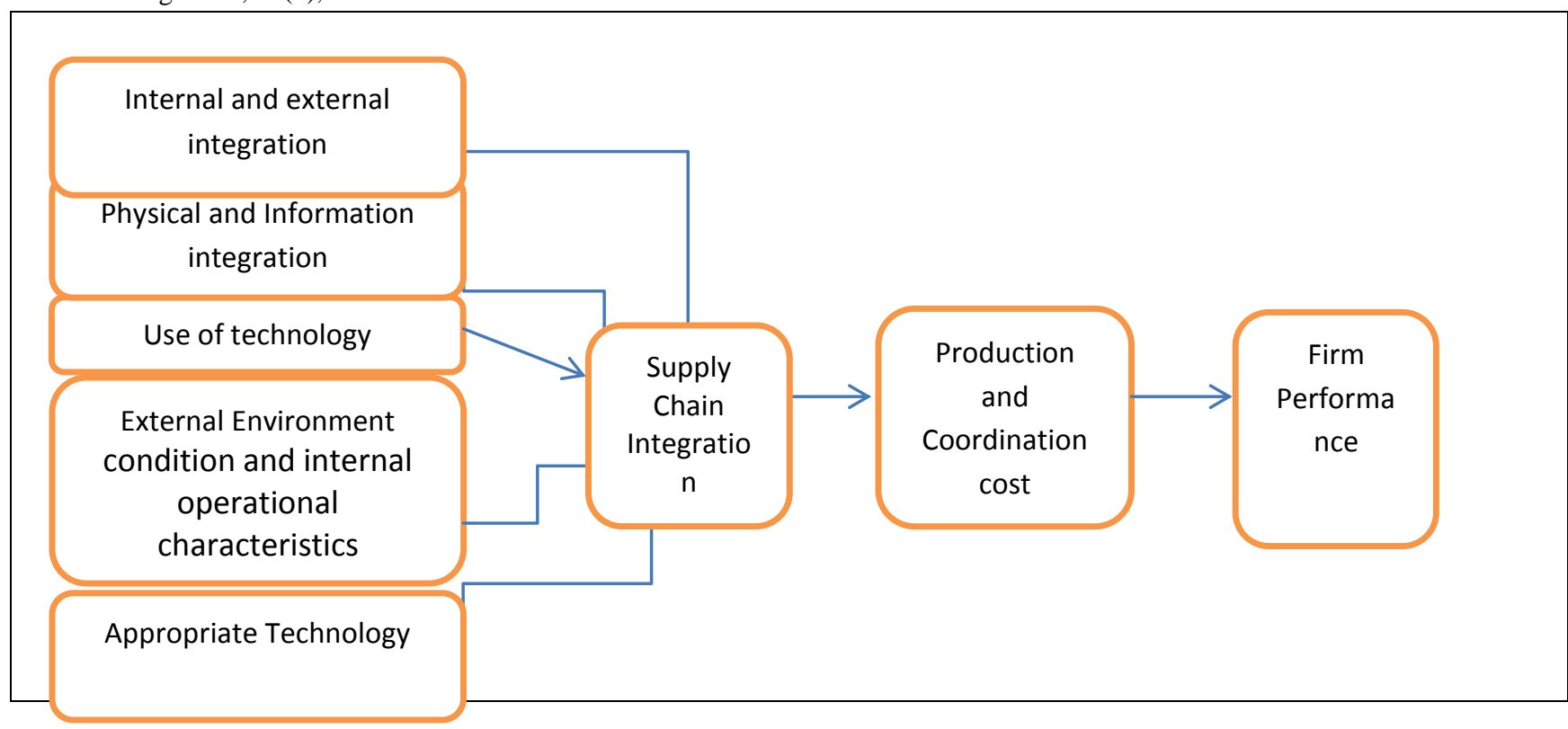

Fig 1: Research Model 